\title{
FINANCIAL RESTRUCTURING DRIVEN BY SINGLE PRESENCE POLICY (SPP) (A CASE STUDY MERGER AT PT. BANK NIAGA TBK AND LIPPO BANK TBK)
}

\author{
Mikael Rommy Kristanto ${ }^{1}$ \\ PT. Perkom Indah Murni \\ Parulian Sihotang ${ }^{2}$ \\ BP MIGAS
}

\begin{abstract}
The issuance of Single Ownership Policy stated in PBI No. $8 / 16 / / \mathrm{PBI} / 2006$ has an implication on the controlling shareholders in more than one bank. The shareholders are given three choices to make adjustment of their structure of ownership in order to match it with the single ownership policy. One of the choices available is merger. At one side, merger can increase its capital and minimize the number of existing banks. On the order side, merger can also result in monopoly that inflicts loss to the fair business competition.

The first objective of Financial Restructuring or Merger is to take measures that avert the impending insolvency and that ensure the sortterm survival of the business. This is the prerequisite for a sustainable restructuring process. The medium and long term goal of financial restructuring is reestablishment of a healthy and solid capital structure.

In Bank Niaga and Lippo Bank merger process was driven by Single Presence Policy which normatively obligates the controlling share holders of a bank to consolidate its share possession by divesting their share, merging or even forming a holding company.

One of the existing controlling share holder by far already got impacted by this policy is Khazanah National Berhad, a foreign investor from Malaysia, who used to control Bank Niaga and Lippo Bank. The SPP indicated its implementation in Indonesia, which

\footnotetext{
${ }^{1}$ PT. Perkom Indah Murni (pure_antarctic@yahoo.com)

${ }^{2}$ Senior Manager BP MIGAS (psihotang@bpmigas.go.id)
} 
foremost align with vision of Indonesian Banking Architecture which is to designate healthy, strong and dynamic national banking structure.

Keywords: financial restructuring, single presence policy, merger, Indonesian banking architecture.

\section{BACKGROUND}

\section{Background}

On July $18^{\text {th }} 2008$, the General Meeting of Extraordinary Shareholders (Rapat Umum Pemegang Saham Luar Biasa - RUPS-LB) which was held in Jakarta, had agreed on the new composition of CIMB Niaga Board of Directors and appointed Mr. Arwin Rasyid as the new President Director.

"We believe that CIMB is capable to become the leading general bank in Indonesia", said Dato Sri Nazir Razak, Chief Executive Officer of CIMB Group during the press conference. The General Meeting also appointed Dato as a Chairman ${ }^{3}$. The General Meeting also appointed Dato as a Chairman.

PT. Bank Niaga Tbk and PT Bank Lippo Tbk finally merged on June $3^{\text {rd }} 2008$ with the new company name: PT. CIMB Niaga Tbk. Merger is a preferable option to comply with the Government's policy requirement about Single Presence Policy (SPP), which was regulated by Bank Indonesia. Single Presence Policy was announced in 2006 covering several policy options:

- To remove some or all of the stocks in one bank or more under the control of another interested party. Therefore, there will be only one shareholder in one bank (diversification or sale of shares).

- To set a Merger and Consolidation to control banks.

- To create a parent company in the banking sector (Bank Holding Company) through these options :

a Appoint one bank as a Holding Company to do the controlling.

b Create a new legal institution as a Bank Holding Company.

\footnotetext{
${ }^{3}$ Quote based on searching in www.kompas.com
} 
Single Presence Policy is a policy adopted by Bank Indonesia to encourage merger and consolidation in order to establish banks with strong capital structure, healthy financial condition, and high competitive capability to run its intermediary function. However, in certain country this policy is not easy to be applied because of the complexity of political and social interest.

\section{Background of Bank Niaga}

Bank Niaga was established on 26 September 1955, and in October 2008 became the sixth largest bank in Indonesia by assets, and the second largest in terms of mortgage lending with 9-10\% market share. The majority of the Bank's equity was held by Bumiputra-Commerce Holdings Berhad (BCHB) since 25 November 2002 and on 16 August 2007 was transferred to CIMB Group, a wholly owned subsidiary of BCHB. As the first local bank to introduce ATM services in 1987 and also an on-line banking system in 1991, Bank Niaga is well-regarded as one of the most innovative banks in Indonesia. With over 6,000 employees, Bank Niaga offers a comprehensive suite of conventional and Syariah banking products and services, from 256 branches in 48 cities in Indonesia.

Through its extensive branch office and ATM network, as well as its wide range of sophisticated electronic channels, Bank Niaga offers a highly personalized banking experience to its customers. Amongst its accolades, in 2007 Bank Niaga was ranked first for 'Performance Management and Training and Development' in The HR Excellence Award 2007 and awarded 'Best Bank' by the Investor Magazine. In 2006, the Bank was awarded 'The Most Consistent Bank in Service Excellence' by Marketing Research Indonesia. For five consecutive years, from 2003-2007, Bank Niaga was awarded The Best Annual Report in Private Financial Listed Companies category.

\section{Background of Lippo Bank}

Lippo Bank was established in March 1948. After a merger with PT Bank Umum Asia, Lippo Bank went public and was listed on the stock exchange in November 1989. The Government of Indonesia acquired a majority shareholding in Lippo Bank after the recapitalization program was executed on 28 May 1999. On 30 September 2005, having obtained approval from Bank Indonesia, Khazanah Nasional Berhad acquired majority ownership Lippo Bank. 
Since then, Lippo Bank has moved quickly to design and carry out a new road-map. The road-map provides Lippo Bank with the tools to meet the rigorous of a world-class bank. As one of E-Banking services pioneers in Indonesia, in October 2008 Lippo Bank becomes a leading private bank in Indonesia, providing quality services and products. Staffed by almost 5,000 employees, it has 408 branches and offices and 741 ATMs across Indonesia. It provides services in more than 100 cities in Indonesia.

\section{Background of Khazanah National Berhad}

CIMB group or Khazanah National Berhad is Malaysia's second largest financial service provider and one of outside East Asia's leading universal banking group. Headquartered in Kuala Lumpur, its key regional offices are located in Singapore, Indonesia and Thailand. CIMB Group is own by Bumiputra-Commerce Holdings Bhd, which listed on Bursa Malaysia with a market capitalization of over US\$ 10 billion. The Group has over 24.000 employees located in 9 countries.

\section{PROBLEM STATEMENT}

These are some problems that this Case Study will try to provide the answers for.

- What is the fundamental driving factors in merging Bank Niaga and Bank Lippo.

- What are the pros and cons when deciding the merge between Bank Niaga dan Bank Lippo.

- Why Bank Niaga survive in this merger process, why not Lippo Bank?

- What are the lessons learned driven from the merger case bewteen Bank Niaga and Lippo Bank.

- Given the global financial crisis, what is the good model for bank merger.

- How much synergy produced from the merger process?

- Is the merger able to improve Bank Niaga performance level aftermerger? 
- Compare the Merger Valuation CIMB Niaga with other banking merger in Indonesia.

\section{LITERATURE REVIEW}

\section{Definition of Financial Restructuring and Merger}

Definition of Financial Restructuring is a process geared at avoiding the liquidation of the Company. Usually it involves agreement by third parties to satisfy creditors claims under certain terms and conditions. Financial restructuring may also be carried out by concluding an agreement with all creditors of the Company under which creditors will be paid on somewhat different terms than those initially accepted by the Company when credit and loans were extended. This form of financial restructuring enables the Company to continue its operations and minimize creditors' losses.

Definition of merger is a combination of two existing firms. In the merger, the acquirer has all the assets and liabilities of the company which acquire. Statutory merger is a merger between two companies where the company aims to support the child or the parent company

Merge can interpreted as merge one company to another company. Merging is usually done with consent of both parties. This means that neither party was winning or losing, because of it is win-win, but it's the nature of mergers to ensure synergy.

\section{Characteristic and Type Merger}

Merger can differentiated into 3 types, there are : Horizontal Merger, Vertical Merger, and Conglomerate Merger

- Horizontal Merger

This type of merge can occur between companies engaged in similar businesses or have similar business (Line of business is same)

Example : Bank merger (Bank of Tokyo with Mitsubitshi Bank in Japan or Chemical Bank and Chase Manhattan Bank in United State of America).

- Vertical merger 
This type of merger can occur as a result of a merger between two companies that their activities at different levels of the production process. In general, mergers of this type carried out by companies that intend to expansion.

- Conglomerate Merger

It is a merger between companies that not the nature of their business related to one another. Different from investment companies that are a combination of a portfolio of investments to reduce risk in an effort to obtain greater profitability.

\section{Healthy for Bank}

Based on the wisdom of government regulation, here are some factors that are typically used to measure productivity and efficiency of the Bank :

- Capitalization (Capital Adequacy Ratio)

$$
\mathrm{CAR}=\frac{\text { Capital }}{\text { Risk Weighted Assets }}
$$

- Asset Quality

Non Performing Loan $\left(\right.$ NPL) $=\frac{\text { Total Loans }}{\text { Inclusive if Inter Bank Loans }}$

- Profitability

$$
\begin{aligned}
& \text { ROA }=\frac{\text { Profit }}{\text { Total Assets }} \\
& \text { ROE }=\frac{\text { Profit }}{\text { Total Equity }}
\end{aligned}
$$

- Liquidity

$$
\text { Loan to Deposit Ratio }=\frac{\text { Loans }}{\text { Profit }}
$$

\section{Synergy}

Merger should give a positive value for the company. The performance of a company after a merger can be seen from the synergies that result. For example, company A merged with company B. Enterprise value of firm A is VA and corporate value of firm B is $\mathrm{VB}$. Value of VA and VB can be obtained by assessing the price of 
shares of the total shares outstanding. The difference between the value of the combined companies (VAB) and the total value of both companies before the merger results in synergy :

$$
\text { Synergy }=V_{A B}-\left(V_{A}+V_{B}\right)
$$

Synergies from the merger may also be calculated with discounted cash flow model as follows :

$\mathrm{T} \quad \Delta \mathrm{CF}_{\mathrm{t}}$

Synergy $=\quad \begin{gathered}\Sigma \\ \mathrm{t}=1\end{gathered}$

Where :

- $\mathrm{CF}=$ the difference between cash flow at $\mathrm{t}$ merger date with the amount of cash flow, cash flows two separate companies, or in addition to the merger date $t$

- $\mathrm{r}=$ risk adjusted discount rate or required rate of return on equity for target company

The Calculation for Incremental Calculation :

$$
C V=\Delta \operatorname{Rev}_{t}-\Delta \operatorname{Cost}_{t}-\Delta \operatorname{Taxes}_{t}-\Delta \text { Capital Requirment }_{t}
$$

Where :

- $\Delta \operatorname{Rev}$

$=$ Incremental Revenue from merger

- $\Delta$ Cost

$=$ Incremental Ccost from merger

- $\Delta$ Tax

$=$ Incremental Tax from merger

- $\Delta$ Capital Requirment in working

$=$ Incremental new investment required

capital and fixed asset. 


\section{METHODOLOGY}

\section{Case Study Methodology}

This case study is using the descriptive quantitative research methods where the research is done by reviewing and analyzing the problem logically arranged based on the relevant facts and theories. The results described systematically to solve the problem in this case study.

\section{Data Collection Technique}

Data used for this case study are as secondary data. Data obtained from literature, through textbooks, articles in magazines, scientific works, the bank's financial statements and other relevant data.

\section{Data Analysis Methods}

Based on the framework, this case study has been prepared using analysis financial Statement method:

1. Analysis the Financial Statement of PT. Bank Niaga Tbk.

$>$ Business Analysis

Business analysis is basis to analyze the company's focus, customer structure, products and services, distribution networks and operations and technology.

$>$ Performance Analysis

The analysis is conducted by looking at the financial statements, and then measures the performance of the banks through the relevant factors, namely:

o Capitalizations : Capital Adequacy Ratio (CAR)

o Productive Assets : Non Performing Loan (NPL)

o Profitability : Return on Asset (ROA)

Return on Equity (ROE)

o Liquidity : Loan to Deposit Ratio (LDR)

Corporate Banking

Conduct corporate banking as an important division of the commercial banking and to study the credit appraisal models supporting the increased activities of corporate lending by banks.

2. Analysis the Financial Statement of PT. Bank Lippo Tbk.

$>$ Business Analysis

Business analysis provide on an analysis of the company's business focus, customer structure, products and services, distribution networks and operations and technology. 
$>$ Performance Analysis

Analysis conduct, looking at data on financial statements, and then measure performance of banks through the relevant factors, namely:

o Capitalizations : Capital Adequancy Ratio (CAR)

o Productive Assets : Non Performing Loan (NPL)

0 Profitability : Return on Asset (ROA)

o Liquidity : Loan to Deposit Ratio (LDR)

Corporate Banking

Conduct corporate banking as an important division of the commercial banking and to study the credit appraisal models supporting the increased activities of corporate lending by banks.

\section{CASE ANALYSIS}

\section{Business Analysis Bank Niaga \\ Business Focus}

In general Retail Banking has recorded a successful year in 2007, Total loans increased $26 \%$ to IDR 41,75 trillion and represented $76 \%$ of total assets as December 2007 (2006 : 71\%) and with an increase of $24,6 \%$ in profit compared to the previous year. On the strength, there's significant $23,7 \%$ growth in loans and $22,7 \%$ increasing in fee based income.

Non Performing Loans (NPL) increased by IDR 432 billion of 37\%, year on year (2006 vs $2005:-23 \%$ ), which resulted in gross NPL ratio increasing from $3,47 \%$ to $3,79 \%$, but it's still below industry average of $40,7 \%$. The three large NPLs from corporate and business banking contributed almost $90 \%$ of NPL raising. However it has been covered by a significant provisioning made during the year which has reduced the net NPL ratio to $2,3 \%$ from the previous $2,51 \%$. NPL coverage ratio increased substantially to $67,58 \%$ in 2007 from $60,07 \%$ in 2006.

\section{Customer Structure}

The biggest Customer structure of Bank Niaga is on Customer Credit, which increased by $26 \%$ in growth and maintained its market share and take place as the second largest mortgage provider institution in the country with market share of around $10 \%$. Business loans 
increased by $38 \%$. Corporate banking business increased by $25 \%$ and manages funds over 26 trillion. Bank Niaga also continued the reorganization and focus on the 3 segments, they are :

- Middle and upper Class

- Residential Mortgage

- Medium Business

\section{Products and Services}

There are several product offered by Bank Niaga on Consumer banking and Commercial business :

- Consumer Banking

Products include funding (savings, term deposits, demand deposits), credit cards, debit cards, private banking, electronic banking services, banking, insurance, mortgage loans (mortgage) and motor vehicle loans, credit versatile, the trustee, the service product (deposit box, money orders, etc.)

- Commercial business

The cover of business financing, such as corporate banking, business banking, small business and trade financing.

\section{Distribution Network}

In providing services to customers, Bank Niaga has a 256 branches spread all over Indonesia and has 469 ATMs and 6650 ATMs Bersama as well spread across Indonesia.

\section{Operations and Technologies}

In terms of technology, Bank Niaga is trying to keep up its reputation as an innovator in the maintenance and implementation of unique concept, which is coffee banking, as well as the further development of easy to use self-service terminals, where the Terminal is that customers can easily access and look at the various aspects and services offered by Bank Niaga.

\section{Business Analysis Lippo Bank Business Focus}

In 2007, Lippo Bank focus was on business growth and expansion, productivity and improvements in systems and processes. Increased day-to-day usage of the network was also a key factor in supporting 
the growth of non interest income which increased by $20 \%$ and now makes up a healthy $31 \%$ of total income.

In the earlier years, the expansion of Lippo Bank's knowledge network was around the key regions and diverse sectors of the economy and the business involved. In addition to understanding key sector developments, attention to comprehend key sector developments, attention is given to maintaining detail to avoid concentration risk. The reduction in Gross non Performing Loans Ratio (NPL) from $2 \%$ in 2006 to $1,5 \%$ is an indicator of the quality Lippo Bank in Credit risk management. Lippo Bank's positions compare well to an average NPL of $4,6 \%$ for the entire banking sector.

Basically, the commercial banking segment of the business is more developed in Lippo Bank. Lippo Bank benefited because it has one of the most expensive funding structure of other banks. This allows the Bank Lippo to give competitive interest rate of debt for both prospective borrowers, which in turn generate revenue growth rate to increased credit expansion and credit quality will support. Revenues result from activities of banking transactions also increased from year to year because Lippo Bank occupies a strong position as a bank for payment and small commercial customers.

Since the end of 2007, Lippo Bank increasingly focus its activities on two pillars, which are, treasury and personal services. In banking consumer segment, Lippo Bank will use its advantages in terms of broad distribution network, a large client base and low-cost financing structure, to deliver innovative consumer loan products to penetrate the consumer banking market which rapidly grew in Indonesia. Although treasury, Bank Lippo will use significant commercial customer base to offer a wide range of products and services, expansion of treasury also bring opportunities for higher returns than managing excess liquidity.

\section{Customer Structure}

Lippo Bank in 2007, the structure divided into customers natural person services and the commercial banks, which includes large corporations, small and medium-sized enterprises. Consumer lending showed $25 \%$ of total loans increased by $57 \%$ to IDR 4.6 trillion. Total 
auto lending increased $102 \%$ to IDR 1,6 trillion. In the commercial sector Lippo Bank boosted SME (UKM) loan by 44\% to IDR 7,7 trillion, otherwise in corporate loan the loan growth rate accelerated by $57 \%$ to IDR 5,8 trillion. There are two categories represent $75 \%$ of the Bank's total loan activity while contributing to $45 \%$ of the total funding base.

\section{Products and Services}

These are the products offered by Bank Lippo in commercial business and consumer segments in the following way:

- Consumer Banking Include savings products, VIP Banking, Credit Cards, Electronic Notes International, Banssurance, Mortgage Loans (KPR) and Motor Vehicle Loans.

- Commercial business

Includes Credit and Working Capital in various economic sectors. There is industry, commerce and public administration, business services, construction, transportation, social services, agriculture, mining, and others.

\section{Distribution Network}

At the end of 2007, Bank Lippo have distribution network of 399 of offices, service centres covering major industry, 150 Branch Offices, 243 Cash Offices and 4 points of payment spread over 87 cities in Indonesia. Lippo Bank also has 714 ATMs spread across 120 cities in Indonesia.

\section{Operations and Technologies}

In addition to using information technology and telecommunications to improve the efficiency. Bank Lippo promotes the concept of centralized operational centres which is carefully planned through creating six separate service centers throughout Indonesia. By the support of IT systems that are reliable, regional operational centres capable of various operating features and reliable communication, operational centres can handle various operational functions, including cleaning and maintenance large scale accounts, so that the scale efficiency can be create. In addition centralizing operations and lower cost savings are done by reducing premise maintenance and buildings for rent cost. 
Bank Lippo continuously developed Banking Technology to evolve the capacity to improve the performance information and referral services, infrastructure, management, compliance and ease of access. Lippo Bank also continued to develop the application one to another with different suppliers of consumer services. Lippo Bank also developed an electronic network financing products supported by innovative technologies.

\section{Analysis of Financial Performance \\ Bank Niaga}

Based on Annual Report 2007, Bank Niaga has net profit received increased by $31 \%$ to IDR 1.5 trillion. Bank Niaga has vision "To be the Premier Universal Bank Indonesia. In 2007, Bank Niaga has achieved good performance, proven to increase ratings in the banking industry, and become the sixth largest bank in terms of assets in Indonesia. The following is a Bank Niaga's financial statement data :

Table 1. Financial Indicator Bank Niaga, PT Tbk

\section{PT. Bank Niaga Tbk}

\begin{tabular}{|c|c|c|c|c|}
\hline Description & 2004 & 2005 & 2006 & 2007 \\
\hline Asset & 30.798 & $\begin{array}{r}41.579 \\
35,01 \% \\
\end{array}$ & $\begin{array}{r}79.891 \\
92,14 \% \\
\end{array}$ & $\begin{array}{r}93.797 \\
17,41 \% \\
\end{array}$ \\
\hline Liabilities & 28.428 & $\begin{array}{r}37.610 \\
32 \% \\
\end{array}$ & $\begin{array}{r}71.748 \\
91 \% \\
\end{array}$ & $\begin{array}{r}84.661 \\
18 \% \\
\end{array}$ \\
\hline Equity & 2.363 & $\begin{array}{r}3.966 \\
68 \% \\
\end{array}$ & $\begin{array}{l}8.138 \\
105 \% \\
\end{array}$ & $\begin{array}{r}9.081 \\
12 \% \\
\end{array}$ \\
\hline Net Income & 660 & $\begin{array}{r}546 \\
-17 \% \\
\end{array}$ & $\begin{array}{l}1.154 \\
111 \% \\
\end{array}$ & $\begin{array}{r}1.508 \\
31 \% \\
\end{array}$ \\
\hline
\end{tabular}

From the table above financial indicators, it can see that the value of the assets, liabilities and equity values of Bank Niaga increased continuously during 2004 - 2007, where the percentage also increased each year. The biggest increasing percentage in assets occurred in 
2006 , which is increased by $92 \%$ compared with 2005 , an increase of IDR 38.312 billion (from IDR 41.579 billion in 2005 to IDR 79.891 billion in 2006).

Increasing in total assets financed with obligations, which values also increased, also the largest increasing occurred in 2006, which increased by $91 \%$ compared with 2005 , an increase of IDR 34.138 billion (from IDR 37.610 billion in 2005 to IDR 71.748 billion).

Increasing amounts of assets and liabilities followed by a capital increase, with the largest percentage increasing also in 2006, is $105 \%$ compared with 2005, an IDR 4.172 billion increasing (from IDR 3.966 billion in 2005 to IDR 8.138 billion in 2006.). A significant capital increasing happened in 2006, Bank Niaga has many divest stock sales which resulted in increases in capital.

For net income value, there is an increasing during the years 2004 2007 , despite a $17 \%$ decreasing in 2005 compared to 2004 , which is from IDR 660 billion to IDR 547 billion. But it did not show declining performance because basically there was increasing in net operating profit in 2005 by $15 \%$ compared to 2004 , which is from IDR 633 billion to IDR 727 billion. It shows better performance due to higher earnings from operations which showed continuous profit.

\section{Lippo Bank}

The following is a Bank Lippo's financial statement data :

Tabel 2. Financial Indicators Bank Lippo, PT Tbk

\section{PT. Bank Lippo Tbk}

\begin{tabular}{|c|c|c|c|c|}
\hline Description & 2004 & 2005 & 2006 & 2007 \\
\hline Asset & 27.832 & $\begin{array}{r}29.116 \\
4,61 \%\end{array}$ & $\begin{array}{c}33.357 \\
14,57 \%\end{array}$ & $\begin{array}{c}38.962 \\
16,80 \%\end{array}$ \\
\hline Liabilities & 25.524 & $\begin{array}{r}26.504 \\
4 \%\end{array}$ & $\begin{array}{r}30.006 \\
13 \%\end{array}$ & $\begin{array}{r}35.033 \\
17 \%\end{array}$ \\
\hline
\end{tabular}




\begin{tabular}{|c|r|r|r|r|}
\hline Equity & 2.308 & 2.611 & 3.351 & 3.878 \\
& & $13 \%$ & $28 \%$ & $16 \%$ \\
\hline \multirow{2}{*}{ Net Income } & 892 & 412 & 506 & 738 \\
& & $-54 \%$ & $23 \%$ & $46 \%$ \\
\hline
\end{tabular}

From the table above financial indicators table above, it can be seen that assets, liabilities and equity values of Lippo Bank increased continuously during 2004 - 2007. The biggest increasing percentage in assets occurred in 2007, which is increased by $17 \%$ compared with 2006, an increase of IDR 5.606 billion (from IDR 33.357 billion in 2006 to IDR 38.962 billion). The growing Asset supported by customer deposit increasing.

Increasing in total assets financed with liabilities, which values also increased. With the largest percentage increasing in liabilities in 2007, by $17 \%$ with a value of IDR 5.027 billion (from IDR 30.006 billion in 2006 to IDR 35.033 billion in 2007.). Increasing amounts of assets and liabilities followed by a capital increasing, with the largest percentage increasing in equity occurred in 2006 , ie by $28 \%$ or equal to IDR 740 billion (from IDR 2.611 billion in 2005 to IDR 3.351 billion in 2006)

In 2005, Lippo Bank suffered losses of IDR 480 billion and then increased dramatically in 2006 and 2007. The largest increasing occurred in 2007, by 46\% or IDR 232 billion (from IDR 506 billion in 2006 to IDR 738 billion in 2007). Decreasing amount of net profit in the year 2005 because there is no transaction costs on sale of property losses taken IDR 112,3 billion. But mostly on the rise in 2005, operating profits at $48 \%$, while net interest income increasing by $30.7 \%$ to IDR 1.222 billion compare with the year 2004. This increase caused by the increase in income interests by $18.7 \%$, while interest expenses increased $6 \%$ due to the financing of profitability. Thus, in 2005, the Lippo Bank performance cannot be said decreasing, because clearly there is an increase in operating earnings more continuity. 


\section{Analysis of Financial Ratio Bank Niaga}

Based on financial ratio analysis, it can be viewed as a whole Bank Niaga Bank has a good level of health with a strong capital structure to keep up its operations (good liquidity) and expansion the credit. Bank Niaga is able to meet the requirements of the Indonesian Banking Architecture (API) with capital more than IDR 100 billion. Bank Niaga even unable to meet the criteria for anchor banks. Bank Indonesia would done associate with merge in banking activities, namely:

- Bank Niaga has capacity to grow and develop properly, supported by a strong and stable capital and has the ability to absorb risks and support business activities. This reflected in the CAR in 2007 's, $15,4 \%$ greater than the minimum $12 \%$.

Table 3. CAR (\%)

\begin{tabular}{|l|c|c|c|c|}
\hline Description & $\mathbf{2 0 0 4}$ & $\mathbf{2 0 0 5}$ & $\mathbf{2 0 0 6}$ & $\mathbf{2 0 0 7}$ \\
\hline Bank Lippo & $19,90 \%$ & $20,80 \%$ & $23,50 \%$ & $20,60 \%$ \\
\hline Bank Niaga & $10,29 \%$ & $17,24 \%$ & $16,65 \%$ & $15,43 \%$ \\
\hline
\end{tabular}

- Bank Niaga also has ability to grow on an ongoing basis as reflected in good profitability. This reflected in the ratio Return on Assets (ROA) 1,61\% and ratio Return on Equity (ROE) 16,61\%

Table 4. ROA

\begin{tabular}{|l|l|l|l|l|}
\hline Description & $\mathbf{2 0 0 4}$ & $\mathbf{2 0 0 5}$ & $\mathbf{2 0 0 6}$ & $\mathbf{2 0 0 7}$ \\
\hline Bank Lippo & $3,21 \%$ & $1,42 \%$ & $1,52 \%$ & $1,89 \%$ \\
Bank Niaga & $2,14 \%$ & $1,32 \%$ & $1,45 \%$ & $1,61 \%$ \\
\hline
\end{tabular}

Table 5. ROE (\%)

\begin{tabular}{|l|c|c|c|c|}
\hline \multicolumn{1}{|c|}{ Description } & $\mathbf{2 0 0 4}$ & $\mathbf{2 0 0 5}$ & $\mathbf{2 0 0 6}$ & $\mathbf{2 0 0 7}$ \\
\hline Bank Lippo & $38,68 \%$ & $15,78 \%$ & $15,12 \%$ & $19,03 \%$ \\
\hline Bank Niaga & $27,94 \%$ & $13,79 \%$ & $14,19 \%$ & $16,61 \%$ \\
\hline
\end{tabular}

- Bank Niaga also play a role in supporting the functions of banking intermediation to ease developing national economy, as reflected in growth of credit expansion, taking into account of the precautionary principle. Growth of credit expansion in real terms by more than $71,82 \%$ of the minimum criteria of $22 \%$ per year, 
LDR treatment $77 \%$ more than the minimum criteria for $50 \%$ and Non Performing Loan (NPL) ratio at 2,71\% below 5\% (net).

Table 6. LDR $(\%)$

\begin{tabular}{|c|r|r|r|r|}
\hline Description & \multicolumn{1}{|c|}{$\mathbf{2 0 0 4}$} & \multicolumn{1}{|c|}{$\mathbf{2 0 0 5}$} & \multicolumn{1}{|c|}{$\mathbf{2 0 0 6}$} & \multicolumn{1}{c|}{$\mathbf{2 0 0 7}$} \\
\hline Bank Lippo & $20 \%$ & $30 \%$ & $43 \%$ & $59 \%$ \\
Bank Niaga & $82 \%$ & $83 \%$ & $67 \%$ & $77 \%$ \\
\hline
\end{tabular}

Table 7. NPL - Net (\%)

\begin{tabular}{|l|c|l|l|}
\hline Description & $\mathbf{2 0 0 5}$ & $\mathbf{2 0 0 6}$ & $\mathbf{2 0 0 7}$ \\
\hline Bank Lippo & $1,35 \%$ & $1,61 \%$ & $0,76 \%$ \\
\hline Bank Niaga & $5,35 \%$ & $2,62 \%$ & $2,71 \%$ \\
\hline
\end{tabular}

Note : The differences NPL Gross and NPL Net, NPL gross is NPL compared the amount of debt in substandard, doubtful, and loss status, united with total debt distributed. While NPL Net only compares loss-status debt with total debt distributed. NPL Net only calculated loss-status debt. While NPL gross also calculated substandard and doubtful status debt, which in the future could be developed into loss-status.

\section{Analysis of Financial Ratio Lippo Bank}

The ratio which is used to measure performance bank is Capital Adequacy Ratio (CAR). CAR compares the capital provided by shareholders with capital should be provided by developing quality assets. Bank Lippo has a CAR which tend to increase every year. Values of CARs also tend higher with an average of 21,2\%. Lippo Bank's CAR is positive with a value large enough to show that capital provided by shareholders is enough to support quality asset increasing. It shows that good performance of Lippo Bank and its ability to increase capital.

The ratio used to measure performance of productive assets is the ratio of Non Performing Loans (NPL). NPL describes the ratio between the productive assets (net) Net of allowance for losses to total loans. In 2007, Bank Lippo has a pretty good NPL, which is $0,76 \%$ (below 5\%).

The ratio which is used to measure the profitability is Return on Assets (ROA) and Return On Equity (ROE). Profitability shows how much the company can give loans to others by measuring the profits 
ratio from assets or equity. Based on calculations, Bank Lippo's ROA and ROE tend to increase and stable compared with Bank Niaga. In 2005 ROA and ROE Bank Lippo has declined, but it can't be said that Bank's activity is going down, because there is an increasing in Net profit and it is more sustainable.

The ratio used to measure performance of banking liquidity is the Loan to Deposit Ratio (LDR). LDR shows a comparison between the credit given to customers with the savings provided by the community. In other words LDR measures how much productive assets can cover the liabilities. Bank Lippo has a LDR with tendency to increase, the largest LDR value in 2007 was $59 \%$, up 6\% compared to 2006 by $43 \%$. LDR increased values, which indicates that the Lippo Bank continues to carry out a very comprehensive credit policy. This shows better performance because Bank Lippo is more liquid with greater proportion of productive assets than liabilities.

Based on the ratio of Lippo Bank, it can be said that, generally Bank Lippo Bank has sustainability and good performance with a capital structure which is strong enough to sustain its credit and expansion operations. Bank Lippo is able to meet the criteria of Bank Indonesia as a bank with a good performance, which are :

- Has IDR 3.878 billion Capital in 2007, it is more than Rp. 100 billion.

- Has minimum Capital Adequacy Ratio of 20,6\% in 2007 which is higher than at least $10 \%$ criteria.

- Has Corporate Governance with greatest rating.

\section{Analysis of Financial Ratio Lippo Bank}

Before merger, one thing to be noted is how to do target company assessment. Target company assessment can be profit oriented or in company assets. Some method which is generally used by assessment consultant companies are Capitalization of maintainable future earnings method and discounted cash flow method based on financial report projection also net asset, market value, and liquidation methods based on asset value. Target company assessment is an important thing to decide appropriateness of stock price to avoid too much higher or lower assessment and investment through overvalue or undervalue stock assessment. 
Table 8. Bank Niaga's Indicators

\begin{tabular}{|l|c|l|l|l|}
\hline PT Bank Niaga Tbk. & \multicolumn{1}{|c|}{$\mathbf{2 0 0 7}$} & \multicolumn{1}{|c|}{$\mathbf{2 0 0 8 F}$} & $\mathbf{2 0 0 9 F}$ & \multicolumn{1}{|c|}{$\mathbf{2 0 1 0 F}$} \\
\hline Net Profit & $1,508,386$ & $8,709,709$ & & \\
\hline EPS & 64.72 & 73 & 105 & \\
\hline Number of Shares & 23,306 & 257,286 & - & \\
\hline Cost Of Capital & $10.60 \%$ & & & \\
\hline & & & & \\
\hline Valuation & & & & \\
\hline DCF & & 0.904159 & 0.817504 & \\
\hline DCV & & $16,916,555$ & - & $16,916,555$ \\
\hline Terminal Value & & & - & - \\
\hline Total Value & & & & $16,916,555$ \\
\hline Intrinsic Value & & & & $\mathbf{7 2 6}$ \\
\hline Market Value & & & & $\mathbf{6 4 0}$ \\
\hline
\end{tabular}

According to the equation, there could be found stock price appropriateness of Bank Niaga is IDR. 640

Table 9. Lippo Bank’s Indicators

\begin{tabular}{|c|c|c|c|c|}
\hline PT Bank Lippo Tbk. & 2007 & $2008 F$ & 2009F & $2010 F$ \\
\hline Net Profit & $21,351,338$ & 310,955 & 448,921 & \\
\hline EPS & 188.45 & 74.77 & 121.33 & \\
\hline Number of Shares & 3,915 & 4,159 & 3,700 & \\
\hline Cost Of Capital & $7 \%$ & & & \\
\hline \multicolumn{5}{|l|}{ Valuation } \\
\hline $\mathrm{DCF}$ & & 0.93245 & 0.86946 & \\
\hline $\mathrm{DCV}$ & & 289,948 & 390,317 & 680,265 \\
\hline Terminal Value & & & $6,645,393$ & $6,645,393$ \\
\hline Total Value & & & & $7,325,659$ \\
\hline Intrinsic Value & & & & 1,871 \\
\hline Market Value & & & & 1,010 \\
\hline
\end{tabular}

According to the equation, there could be found stock price appropriateness of Lippo Bank is IDR. 1,010 
Table 10. CIMB Niaga's Indicators

\begin{tabular}{|l|l|l|l|l|}
\hline \multicolumn{1}{|c|}{ CIMB NIAGA } & \multicolumn{1}{|c|}{$\mathbf{2 0 0 7}$} & \multicolumn{1}{c|}{ 2008F } & \multicolumn{1}{c|}{ 2009F } & 2010F \\
\hline Net Profit & $25,068,037$ & $1,038,694$ & $1,269,863$ & \\
\hline EPS & 63 & 68 & 83 & \\
\hline Number of Shares & 15,284 & 15,284 & 15,284 & \\
\hline Cost Of Capital & $8 \%$ & & & \\
\hline & & & & \\
\hline Valuation & & & & \\
\hline DCF & & 0.926102 & 0.857665 & \\
\hline DCV & & 961,937 & $1,089,116$ & $2,051,053$ \\
\hline Terminal Value & & & $12,640,320$ & $12,640,320$ \\
\hline Total Value & & & & $14,691,373$ \\
\hline Intrinsic Value & & & & $\mathbf{9 6 1}$ \\
\hline Market Value & & & & \\
\hline
\end{tabular}

According to the equation, there could be found stock price appropriateness of CIMB Niaga is IDR. 961

- The Synergy Intrinsic Value $(9,550,841)$

- The Synergy Market Capitalization $(8,041,396)$

Table 11. Synergy

\begin{tabular}{|l|l|}
\hline Total Value & $7,011,088$ \\
\hline Total Value & $7,325,659$ \\
\hline Total Value & $14,691,373$ \\
\hline Synergy & 354,626 \\
\hline
\end{tabular}

Value to the Firm of Bank Niaga is IDR 16,916,555 and value to the firm of Lippo Bank is IDR 7,325,659. Meanwhile, Value to the firm CIMB Niaga post-merger is IDR 14,691,373. According to calculation above, it can be seen there is an aggregate in form of synergy for IDR 354,626

Synergy calculation produced positive value shows that the merger produced better value to the firm. It signed that the company would be able to give positive growth in the future. By doing merger, Bank Niaga after merger could do business development through more expansive debt policy, also pressing company's operational cost. 


\section{Compare to Other Merger (ANK with Commonwealth)}

Table 12. Details of ANK's Net Assets Received and Goodwill

\begin{tabular}{|c|c|}
\hline Net assets & 124,022 \\
\hline Adjustment to fair value of net asset & 34,959 \\
\hline Fair value of net assets & 158,981 \\
\hline Purchase price*) & 321,159 \\
\hline Goodwill & 162,178 \\
\hline
\end{tabular}

Goodwill is being amortised over five years. Goodwill amortisation up to 31 December 2007 amounting to Rp 11,194 and was charged to the statement of income.

\section{ANK's Shares}

The Total of Shares : $157,711,000$ shares

Tender offer price $: 1.660$ IDR

Aquisition of ANK : 266,652 in million IDR (in Commonwealth financial statement 2007)

Table 13. Share ANK After Acquisition (July 2007)

\begin{tabular}{|l|l|l|}
\hline \multicolumn{1}{|c|}{ Company } & \multicolumn{1}{c|}{ Shares } & \multicolumn{1}{c|}{ Percentage } \\
\hline $\begin{array}{l}\text { PT Bank } \\
\text { Commonwealth }\end{array}$ & $157,711,000$ & $83.00 \%$ \\
\hline PT Giga Galaxy & $9,686,700$ & $5.00 \%$ \\
\hline PT Murni Galaxy & $9,686,700$ & $5.00 \%$ \\
\hline
\end{tabular}




\section{Commonwealth Performance After Acquisition}

Table14. Balance Sheet Commonwealth

\begin{tabular}{|c|c|c|c|c|c|c|c|}
\hline $\begin{array}{r}\text { Neraca } \\
\text { Balance Sheet }\end{array}$ & 2003 & 2004 & 2005 & 2006 & $2007^{8}$ & 2008 & 2009 \\
\hline $\begin{array}{l}\text { Total Aktiva } \\
\text { Total Assets }\end{array}$ & $1,975,890$ & $2,359,196$ & $5,446,156$ & $4,868,661$ & $6,354,640$ & $11,623,771$ & $11,350,753$ \\
\hline $\begin{array}{l}\text { Aktiva Produktif } \\
\text { Total Earning Assets }\end{array}$ & $1,898,505$ & $2,233,768$ & $4,924,178$ & $4,514,740$ & $5,578,673$ & $10,586,136$ & $10,159,359$ \\
\hline $\begin{array}{r}\text { Total Kredit } \\
\text { Total Loans }{ }^{9}\end{array}$ & 26,805 & 205,458 & 992,240 & $1,747,314$ & $3,141,944$ & $4,748,290$ & $4,766,246$ \\
\hline $\begin{array}{r}\text { Surat-surat Berharga } \\
\text { Marketable Securities }{ }^{9}\end{array}$ & $1,206,710$ & 952,045 & $2,693,587$ & $1,661,548$ & $1,123,244$ & $3,340,873$ & $3,311,834$ \\
\hline $\begin{array}{l}\text { Dana Pihak Ketiga } \\
\text { Third Party Funds }{ }^{1}\end{array}$ & $1,805,907$ & $2,164,156$ & $5,078,975$ & $4,148,313$ & $5,318,635$ & $10,082,679$ & $10,101,848$ \\
\hline $\begin{array}{r}\text { Giro } \\
\text { Current Accounts } \\
\end{array}$ & 128,352 & 207,597 & 256,681 & 475,462 & 608,282 & 556,899 & 643,771 \\
\hline $\begin{array}{r}\text { Tabungan } \\
\text { Savings } \\
\end{array}$ & 277,745 & 90,385 & 145,586 & 590,877 & 900,521 & $1,992,777$ & $1,561,932$ \\
\hline $\begin{array}{r}\text { Simpanan Berjangka } \\
\text { Time Deposits } \\
\end{array}$ & $1,399,810$ & $1,866,174$ & $4,676,708$ & $3,081,974$ & $3,809,832$ & $7,533,003$ & $7,896,145$ \\
\hline $\begin{array}{r}\text { Pinjaman yang Diterima } \\
\text { Borrowings }^{2}\end{array}$ & - & 11,000 & 49,150 & 199,385 & 221,172 & 387,675 & 14,998 \\
\hline $\begin{array}{l}\text { Modal Saham } \\
\text { Shareholders Equity }\end{array}$ & 143,273 & 149,653 & 227,918 & 420,475 & 649,349 & 888,769 & 982,078 \\
\hline
\end{tabular}

Table 15. Income Statement Commonwealth

\begin{tabular}{|c|c|c|c|c|c|c|c|}
\hline $\begin{array}{l}\text { Laporan Laba Rugi } \\
\text { Statement of Income }\end{array}$ & 2003 & 2004 & 2005 & 2006 & $2007^{8}$ & 2008 & 2009 \\
\hline $\begin{array}{r}\text { Pendapatan Bunga Bersih } \\
\text { Net Interest Income }\end{array}$ & 33,196 & 53,693 & 82,579 & 170,464 & 237,254 & 309,881 & 428,352 \\
\hline $\begin{array}{r}\text { Pendapatan Operasional Lainnya } \\
\text { Other Operational Income }\end{array}$ & 27,339 & 36,289 & 76,529 & 62,607 & 222,513 & 268,238 & 285,126 \\
\hline $\begin{array}{c}\text { Biaya Operasional Lainnya } \\
\text { Other Operational Expenses }\end{array}$ & $(57,170)$ & $(75,373)$ & $(142,394)$ & $(214,121)$ & $(375,199)$ & $(503,206)$ & $(589,611)$ \\
\hline $\begin{array}{l}\text { Biaya Penyisinan Kerugian Aktiva Produktif } \\
\text { Provision for Losses on Earning Assets }\end{array}$ & (217) & $(4,925)$ & $(10,654)$ & $(15,529)$ & $(26,900)$ & $(37,739)$ & $(79,635)$ \\
\hline $\begin{array}{c}\text { Laba Operasional Besih } \\
\text { Net Operating Income }\end{array}$ & 3,148 & 9,684 & 6,060 & 3,421 & 57,668 & 37,174 & 44,232 \\
\hline $\begin{array}{l}\text { Laba Sebelum Beban Pajak Penghasilan Badan } \\
\text { Income Before Corporate Income Tax Expense }\end{array}$ & 3,667 & 9,684 & 6,060 & 3,421 & 57,448 & 32,726 & 37,997 \\
\hline $\begin{array}{ll}\text { Laba Bersih } \\
\text { Net Income }\end{array}$ & 2,143 & 6,380 & 3,265 & 760 & 30,712 & 1,756 & 7,841 \\
\hline
\end{tabular}

Table 16. Financial Ratios Commonwealth

\begin{tabular}{|c|c|c|c|c|c|c|c|}
\hline \multirow[b]{2}{*}{$\begin{array}{r}\text { Rasio Keuangan } \\
\text { Financial Ratios }\end{array}$} & \multirow[b]{2}{*}{2003} & & & & & \multirow[b]{2}{*}{2008} & \multirow[b]{2}{*}{2009} \\
\hline & & 2004 & 2005 & 2000 & $2007^{8}$ & & \\
\hline $\begin{array}{r}\text { Rasio Laba Sebelum Pajak Terhadap Rata-rata Total Aset } \\
\text { Return on Average Assets }{ }^{3}\end{array}$ & $0.20 \%$ & $0.45 \%$ & $0.16 \%$ & $0.07 \%$ & $1.03 \%$ & $0.41 \%$ & $0.39 \%$ \\
\hline $\begin{array}{r}\text { Rasio Laba Setelah Pajak Terhadap Rata-rata Ekuitas } \\
\text { Return on Average Equity }{ }^{4}\end{array}$ & $1.51 \%$ & $4.36 \%$ & $1.73 \%$ & $0.23 \%$ & $5.74 \%$ & $0.23 \%$ & $0.84 \%$ \\
\hline $\begin{array}{r}\text { Marjin Pendapatan Bersih } \\
\text { Net Interest Margin } 5\end{array}$ & $1.75 \%$ & $2.40 \%$ & $1.68 \%$ & $3.78 \%$ & $4.25 \%$ & $2.93 \%$ & $4.22 \%$ \\
\hline $\begin{array}{r}\text { Rasio Kecukupan Modal } \\
\text { Capital Adequacy Ratio }(C A R)^{6}\end{array}$ & $85.52 \%$ & $32.52 \%$ & $17.20 \%$ & $21.71 \%$ & $15.39 \%$ & $14.52 \%$ & $16.32 \%$ \\
\hline $\begin{array}{r}\text { Rasio Kredit Terhadap Dana Pihak Ketiga } \\
\text { Loan to Deposit Ratio (LDR) }\end{array}$ & $1.48 \%$ & $9.49 \%$ & $19.54 \%$ & $42.12 \%$ & $59.07 \%$ & $47.09 \%$ & $47.18 \%$ \\
\hline $\begin{array}{l}\text { Rasio Non Performing Loan } \\
\text { Non Performing Loan Ratio }\end{array}$ & Nil & Nil & $0.03 \%$ & $0.13 \%$ & $0.56 \%$ & $1.03 \%$ & $1.40 \%$ \\
\hline
\end{tabular}


Table 17. Other Key Indicators Commonwealth

\begin{tabular}{r|r|r|r|r|r|r|r}
$\begin{array}{r}\text { Indikator Utama Lainnya } \\
\text { Others Key Indicator }\end{array}$ & 2003 & 2004 & 2005 & 2006 & $2007^{8}$ & 2008 & 2009 \\
\hline $\begin{array}{r}\text { Jumlah Nasabah } \\
\text { Number of Customer }\end{array}$ & 8,815 & 19,269 & 106,604 & 204,072 & 299,044 & 430,504 & 449,520 \\
\hline $\begin{array}{r}\text { Jumlah Cabang } \\
\text { Number of Branches }\end{array}$ & 6 & 8 & 15 & 21 & 47 & 56 & 74 \\
\hline $\begin{array}{r}\text { Jumlan Karyawan } \\
\text { Number of FTE }\end{array}$ & 168 & 250 & 395 & 506 & 982 & 1,463 & 1,504 \\
\hline $\begin{array}{r}\text { Kinerja Kualitas Pelayanan Keseluruhan } \\
\text { Service Quality Overall Performance }\end{array}$ & $75.84 \%$ & $80.78 \%$ & $81.76 \%$ & $84.67 \%$ & $89.41 \%$ & $90.11 \%$ & $90.70 \%$ \\
\hline
\end{tabular}

\section{CONCLUSIONS AND RECOMMENDATION}

\section{Conclusion}

Single Presence Policy from policy listed in PBI No.8/16/PBI/2006 enable stockholders controlling in more than one bank. Stockholders are given three options to adapt their ownership structure in order to adapt the Single Presence Policy (SPP). One of the provided options is merger. In one side, merger is able to raise capital and reduce the number of existing banks. In other side, merger can also cause monopoly, cause loss in health competition, which was described in Indonesian Banking Architecture (Arsitektur Perbankan Indonesia API).

Merger and acquisition is part of strategy adopted by central bank to create competitive Indonesia banking industry in global market. The merger between Bank Niaga and Lippo Bank will form the fifth largest bank in Indonesia in terms of asset, by combining the strengths of both banks and competing and growing in the increasingly competitive Indonesian banking sector. For CIMB Group, the merger will strengthen its position as a leading South East Asian franchise and enhance its growth prospects and earnings complexion.

Khazanah Merger Team has agreed to choose Bank Niaga as surviving entity in this merger because they notice that Bank Niaga has a larger asset value compared to Lippo Bank. Otherwise, choosing Bank Lippo would take cost from Bank Niaga for funding. However, Bank Lippo has strength in retail market with lower interest level and higher performance in financial report of 2004-2007. Their company management had improved and it helps to gain investment, increases the efficiency and enables a long-term growth development. And also, 
financial health of Lippo Bank has been maintained, especially because of prudent liability management.

The merging company's financial performance efficiency and proxy should according to the standard described in financial performance to decide the successful rate. This measurement can be seen from financial ratio such as: CAR, NPL, LDR, ROA, and ROE.

Bank Niaga has some improving assets, liabilities, equity, and net profit. Bank Niaga performance can also be viewed from banking financial ratio which shows better performance. Bank Niaga has excellent bank health measurement. Even it is able to meet Bank Indonesia criteria to be the anchor bank in consolidation process with CAR rate $15,4 \%$, non performing loan rate $2,71 \%$, Return on Assets rate $1,61 \%$, rate $16,61 \%$ ROE and LDR rate is $77 \%$ in 2007 . Bank Niaga Commerce also took the sixth place in banking sector in term of assets.

Lippo Bank also has improving assets, liabilities, equity, and netprofit. Lippo Bank performance can be viewed from various banking financial ratio which shows better performance in 2007, by CAR rate CAR $2,6 \%$, NPL $0,76 \%$, ROA rate $1,89 \%$, ROE rate $19,03 \%$, and LDR rate $59 \%$. From financial ratio analysis in 2007, Bank Lippo seems to have better performance than Bank Niaga and it also meet the Indonesian Banking Architecture (Arsitektur Perbankan Indonesia - API) with more than IDR 100 billion ownership.

As result of the merger, the bank offers its customer a complete portfolio of product and service. In addition, its customer can access for this facility, it has also developed by network expansion selling and distribution. On the other side, merger can be proved really useful in fighting market competition, as merger has the capability to generate economies of scale. These Economies of scale can help the banks in lowering their servicing cost and in this way can provide a competitive edge to them.

\section{Recommendation}

Based on research that has done, I suggestion that be given, as follows : 
- Merger between Bank Niaga and Lippo Bank CIMB Niaga would be excellent thing for both owners. By creating two banks individually, it would create competition between them. From owner side, Commerce Asset Holdings Berhard, Malaysia, should do more in planning and fund source used for consolidation and merger. Also they should do analysis before selecting which bank to be survived in merger process. Don't just view volume in assets, company management also important. Lippo Bank has better corporate governance and comparing Bank Niaga business structure. Bank restructuring should move from stage to stage of recapitalization, stabilization, and rehabilitation and also restructuring operation.

- Merger between Bank Niaga and Lippo Bank make Synergy and it is positive value, It is sign that the company would be able to give positive growth in the future. By doing merger, Bank Niaga after merger could do business development through more expansive debt policy, also pressing company's operational cost.

- To develop performance after merger, CIMB Niaga assures the customer that merger is able to develop better performance. CIMB Niaga has innovated through product creation with high competitiveness to fulfill difference customer needs. Through Merger, CIMB Niaga should also expand business focus, customer structure, and branch and ATM expansion. Consolidation can also be used as symbolic trading to create cross-selling client between Bank Niaga and Lippo Bank.

\section{REFERENCES}

Bank Indonesis. (2011). Peraturan Perbankan, Retrieved 10 June 2011. http://www.bi.go.id/web/id/Peraturan/Perbankan/

CIMB Niaga. (2011). About Us, Retrieved 15 May 2011. http://www.cimbniaga.com/index.php?ch=gen_about\&pg=gen about us\&ac

Damodaran, Aswath. (1996). Investment Valuation : Tools and Techniques for Detemaining The Value of Any Assets. New York: John Willey and Sons. 
Damodaran, Aswath. (1996). Corporate Finance Theory and Practice. New York: John Willey and Sons.

Emery, Douglas R. And John D Finnerty. (1997). Coorporate Finance Management, New Jersey: Prentice Hall.

Fred J. Wetson, Kwang S. Chun, Susan E. Hoag. (1990). Merger, Restructuring and Corporate Control. New Jersey: Prentice Hall.

Fridson, Martin \& Alvarez, F. (2002). Financial Statement Analysis $3^{\text {rd }}$ ed. Canada: John Wiley \& sons, Inc.

Gaughan, Patrick A. (2007). Mergers, Acquisition and Corporate Restructuring. Canada: John Willey and Sons.

Infobank News. (2011). Perbankan, Retrieved 20 July 2011. www.infobanknews.com/category/perbankan/

Jhonsen, H. J. (1995). Bank Merger, Aquisition and Strategic Alliances; Positioning and Protecting Your Bank in The Era of Consolidation. Illionis : Irwin.

Jae K. Shin/ Joel G. Siegel. (1992). The Vest Pocket cfo. New Jersey : Prentice Hall, Englewood Cliffts.

Krallinger, Joseph. (1997) Merger and Aquisition: Managing the Transaction. New York: McGraw Hill.

Lovallo, D., P. Viguerie, R. Uhlaner and J. Horn. 2007. Deals without delusions. Harvard Business Review (December): 92-99. (Mergers \& acquisitions).

Ross, Stephen A. (2005). Corporate Finance. Canada: McGraw Hill International Edition.

Republika. (2011). Merger Niaga-Lippo, Retrieved 13 June 2011. http://www.republika.co.id/berita/breakingnews/ekonomi/08/09/22/4291-merger-niaga-lippo-selesaimedio-2009

Tempo. (2011). Khazanah Jajaki Merger Lippo dan Niaga, Retrieved 20 May 2011. http://www.tempo.co/read/news/2007/12/27/056114257/Khaz anah-Jajaki-Merger-Lippo-dan-Niaga 
Wild, John J., Halsey. (2004). Financial Statement Analysis. New York: Robert F.

Wild, John \& Subramanyan, K.R. (2008). Financial Statement Analysis $10^{\text {th }}$ ed, Chapter6. New York: Mc. Graw Hill. 